\title{
Correction to: Establishing a Suitable Soil Quality Index for Semi-Arid Rangeland Ecosystems in Northwest of Iran
}

\author{
Esmaeil Sheidai Karkaj ${ }^{1} \cdot$ Adel Sepehry $^{2} \cdot$ Hossein Barani $^{2} \cdot$ Javad Motamedi $^{3} \cdot$ Farzin Shahbazi $^{4}$
}

Published online: 9 September 2019

(C) Sociedad Chilena de la Ciencia del Suelo 2019

\section{Correction to: Journal of Soil Science and Plant Nutrition https://doi.org/10.1007/s42729-019-00065-4}

There was an error in this article as originally published.

The surname of coauthor Farzin Shahbazi was misspelled as "Shahbzi".

The original article has been corrected.

Publisher's Note Springer Nature remains neutral with regard to jurisdictional claims in published maps and institutional affiliations.

The online version of the original article can be found at https://doi.org/ 10.1007/s42729-019-00065-4

Esmaeil Sheidai Karkaj

e.sheidai@urmia.ac.ir

1 Department of Range and Watershed Management, Faculty of Agriculture and Natural Resources, Urmia University, Urmia, Iran

2 Department of Rangeland Management, Faculty of Rangeland and Watershed Management, Gorgan University of Agricultural Sciences and Natural Resources, Gorgan, Iran

3 Rangeland Research Division, Research Institute of Forests and Rangelands, Agricultural Research Education and Extension Organization (AREEO), Tehran, Iran

4 Department of Soil Science and Engineering, Faculty of Agriculture, University of Tabriz, Tabriz, Iran 